\title{
Non-carcass component yield of lambs finished in distinct production systems
}

\section{Rendimento dos componentes não carcaça de cordeiros terminados em diferentes sistemas de produção}

\author{
Daniel Gonçalves da Silva ${ }^{*}$; Vicente de Paulo Macedo²; Magali Floriano da \\ Silveira ${ }^{2}$; Ana Carolina Fluck ${ }^{2}$; Olmar Antônio Denardin Costa ${ }^{3}$; Francisco Antonio \\ Piran Filho ${ }^{1}$; Claudio Bortoluzzi ${ }^{4}$; Patricia Franzosi ${ }^{4}$
}

\begin{abstract}
The aim was to assess the effect of the production system on the yield of non-carcass components of Dorper x Santa Inês crossbred lambs. The study was carried out at the teaching and research unit of sheep and goats of the Universidade Tecnológica Federal do Paraná, Campus Dois Vizinhos - PR using 24 uncastrated Dorper x Santa Inês crossbreed lambs ( 8 animals per treatment). The experimental design was completely randomized using three treatments with eight replicates. The treatments were: Panicum maximum cv. Aruana pasture, no shade, and no concentrate supplementation (PAss); Panicum maximum cv. Aruana pasture in the shade of Louro-Pardo Nativo trees (Cordia trichotoma) and with concentrate supplementation (PAcs); feedlot pens (COp). Carcass weight did not differ between treatments ( $p$ $>0.05$ ). However, sheep in feedlot pens showed higher average daily weight gain. The non-carcass components differed significantly $(\mathrm{p}<0.05)$, apart from the empty gastrointestinal tract, respiratory tract, and reproductive organs. Blood and external body components (head, skin, and limbs) showed higher weight in COp animals. The full gastrointestinal tract showed a significant difference between the treatments with the highest weight in sheep in the two pasture systems. Blood yield and weight of liver, kidneys, spleen, and heart were higher in COp animals. The production systems thus affected the total mass of non-carcass components in Dorper x Santa Inês crossbred lambs.
\end{abstract}

Key words: Aruana pasture. Crossbred Lambs. Feedlot. Silvopastural.

\section{Resumo}

O objetivo deste trabalho foi verificar a influência dos sistemas de produção sobre o rendimento dos componentes não carcaça de cordeiros mestiços Dorper x Santa Inês. O trabalho foi conduzido na Unidade de Ensino e Pesquisa (UNEPE) de ovinos e caprinos da Universidade Tecnológica Federal do Paraná (UTFPR), Campus Dois Vizinhos - PR. Foram utilizados 24 cordeiros não castrados (8 animais em cada tratamento) provenientes de cruzamento das raças Dorper x Santa Inês. O delineamento

1 DiscenteS, Programa de Pós-Graduação em Zootecnia, Universidade Tecnológica Federal do Paraná, UTFPR, Dois Vizinhos, PR, Brasil. E-mail: danielgonzootec@gmail.com; chicofapf@gmail.com

2 Profs., Coordenação do curso de Zootecnia, Universidade Tecnológica Federal do Paraná, UTFPR, Dois Vizinhos, PR, Brasil. vicentepmacedo@utfpr.edu.br; magalisilveira@utfpr.edu.br; anacarolinafluck@yahoo.com.br

3 Pós-Doutorando, Programa de Pós-Graduação em Zootecnia, Universidade Tecnológica Federal do Paraná, UTFPR, Dois Vizinhos, PR, Brasil. E-mail: odenardin@gmail.com

4 Discentes, Curso de Zootecnia, Universidade Tecnológica Federal do Paraná, UTFPR, Dois Vizinhos, PR, Brasil. E-mail: claudio110996@hotmail.com; patricia.franzosi@live.com.

* Author for correspondence 
experimental foi o inteiramente casualizado, com 3 tratamentos e 8 repetições. Os tratamentos foram: pastagem de Panicum maximum cv. Aruana, sem sombreamento + suplementação alimentar (PAss); pastagem de Panicum maximum cv. Aruana, com sombreamento natural proporcionado pela espécie arbórea Louro-Pardo Nativo (Cordia trichotoma) + suplementação alimentar (PAcs) e confinamento em aprisco (COp). O peso ao abate não apresentou diferença significativa $(\mathrm{P}<0,05)$ entre os tratamentos, já o ganho de peso médio diário teve resultado superior para o confinamento. Os componentes não-carcaça, com exceção do trato gastrointestinal vazio, aparelho respiratório e reprodutor; apresentaram diferenças significativas $(\mathrm{P}<0,05)$ entre os tratamentos. Sangue e os componentes corporais externos (cabeça, pele e extremidade dos membros locomotores) tiveram melhor rendimento nos animais terminados em confinamento. $\mathrm{O}$ trato gastrintestinal cheio apresentou diferença significativa $(\mathrm{P}<0,05)$ entre os tratamentos, com valores superiores observados na pastagem de aruana sem sombreamento e com sombreamento (silvipastoril). O rendimento do sangue, fígado, rins, baço e coração foram maiores nos animais terminados em confinamento. Os sistemas de produção estudados influenciaram no rendimento dos componentes não carcaça de cordeiros mestiços Dorper x Santa Inês.

Palavras-chave: Confinamento. Cordeiros Cruzados. Pastagem de aruana. Silvipastoril.

\section{Introduction}

Lamb carcass is the major product of commercial sheep farming. Meat production, however, entails the production of 'non-carcass' components, such as heart, liver, pancreas, thymus, kidneys, spleen, esophagus, stomach, small intestines, which are edible, and blood, skin, head, and limbs, which are considered inedible (BRASIL, 2017; SILVA SOBRINHO, 2006), depending on regional culture local cuisines. Typically, the term 'non-carcass component' is used for organs and edible viscera (LIMA et al., 2013). These components contain poly-unsaturated fatty acids, iron, and zinc at higher concentrations than in meat, as well as phosphorus, sodium, and potassium (HUTCHISON et al., 1987; COSTA et al., 2007). Non-carcass components are an additional source of revenue because they can be used in the production of sausages or other dishes with a nutritional value that is comparable to that of meat (SANTOS et al., 2005).

The yield of non-carcass components is affected by individual factors and environmental conditions, predominantly by the production systems (PÉREZ; CARVALHO, 2002; ANDRADE et al., 2009). Therefore, pasture and feedlot systems were presumed to affect the performance of sheep and, determining the underlying factors in order to adjust these systems may help achieve optimal performance. Efficient management of sheep in different production systems is necessary to standardize carcasses to the consumers' demands such as that for tender meat with moderate fat content.

Therefore, it is important to assess and compare the effects of pasture and feedlot systems on noncarcass components which can account for up to $16 \%$ of the commercial value of the live animal. These components are a low-cost source of animal protein and are therefore also of interest for the food market for low-income consumers (MATTOS et al., 2006; COSTA et al., 2007). The objective of this study was to assess the influence of production systems on the yield of non-carcass components of Dorper x Santa Inês crossbred lambs.

\section{Material and Methods}

The study was conducted at the teaching and research unit of sheep and goats of the Universidade Tecnológica Federal do Paraná (UTFPR), Dois Vizinhos Campus - PR, Brazil. The study commenced in December 2016 and terminated in March 2017 with a total study period of 117 days. The mean temperature and relative humidity during this time were $22.74{ }^{\circ} \mathrm{C}$ and $76.19 \%$, respectively. Meteorological data were collected at the UTFPR - Dois Vizinhos meteorological station, which was located at a distance of approximately $200 \mathrm{~m}$ from the study area. 
All experiments were conducted according to the ethical guidelines of the Committee on Ethics and Use of Animals (CEUA - UTFPR; approval number 2016/28). Twenty-four non-castrated Dorper x Santa Inês crossbred lambs purchased from a private breeder after weaning were used (eight animals per treatment). The experimental design was completely randomized with three treatments and eight repetitions. The treatments were designed as follows: a Panicum maximum cv. Aruana pasture, no shading and no diet supplementation with concentrate (PAss); P. maximum cv. Aruana pasture shaded by Louro-Pardo Nativo (Cordia trichotoma) trees and diet supplementation with concentrate (PAcs); confinement in feedlot sheep pens (COp). In the PAss and PAcs treatments, concentrate was supplied daily at a dry matter (DM) quantity corresponding to $1.5 \%$ of the body weight (BW).

For the Pass treatment, the total accessible area of $1600 \mathrm{~m}^{2}$ was subdivided into four equal-sized plots of $400 \mathrm{~m}^{2}$, which were fitted with troughs and drinking fountains. The same spatial distribution was applied for the PAcs treatment. The PAcs plots was set up in September 2013 in an east-west orientation in line with Louro-Pardo Nativo trees in double rows with $2 \mathrm{~m}$ distance between trees within and $1 \mathrm{~m}$ between rows. The distance between a ridge (a set of trees formed by a double line) from one paddock to another was approximately $10 \mathrm{~m}$. The average tree height at the time of the study was 6.20 $\mathrm{m}$ and the diameter at chest height was $9.28 \mathrm{~cm}$.

The diet in the COp treatment was formulated to provide a proportion of 20:80 of roughage (ryegrass hay) to concentrate. Diets were adjusted to daily intake, provide ad libitum, to provide about $10 \%$ excess food (i.e. leftover). Eight bays (one per individual) of $4 \mathrm{~m}^{2}$ each were used, which were fitted with feeders, drinking fountains, and salt licks.

Animals of the same age and breed were used; the lambs were weighed using a digital scale with a maximum capacity of $250 \mathrm{~kg}$ on the first day and at 21-day intervals to estimate the average daily weight gain (DWG). During weighing, a subjective assessment of body condition was performed according to Russel et al. (1969).

Mean BW, body condition score (BCS), and age (in days) at the beginning of the experiment were respectively $23.54 \pm 1.53 \mathrm{~kg}$, BCS $2.43 \pm 0.16$, and $139 \pm 3.62$ days in the Pass treatment, $23.12 \pm 2.23$ $\mathrm{kg}$, BCS $2.50 \pm 0.35$, and $136 \pm 6.70$ days in the PAcs treatment, and $22.24 \pm 1.85 \mathrm{~kg}$, BCS $2.14 \pm$ 0.33 , and $140 \pm 6.87$ days in the COp treatment.

The animals were fed two equal rations each day, at 8.00 a.m. and at 3.00 p.m. The diets of lambs on pasture and COp lambs were formulated according to the nutritional requirements of lambs for finishing to contain $18 \%$ crude protein and $73 \%$ total digestible nutrients (NRC, 2007). Commercial mineral salt was supplied at approximately 20 g per animal per day. The chemical composition of the diet and ingredient proportions are shown in Tables 1 and 2 , respectively.

Regarding the treatments corresponding to pasture utilization, we considered the grazing method with continuous stocking and variable stocking rate to correspond to the put-and-take technique (MOTT; LUCAS, 1952). Pasture evaluations were performed at intervals of 21 days, aiming to maintain a constant supply of $10 \%$ (10 kg DM per $100 \mathrm{~kg}$ BW per day). Forage grazing and forage mass estimation ([FM], $\mathrm{kg} / \mathrm{ha} \mathrm{DM}$ ) were performed using a double sampling method (WILM et al., 1944). Pasture grass height was measured using a graded ruler at random points in the pens. Average FM in PAss and PAcs treatments was $2440.87 \mathrm{~kg} / \mathrm{ha} \mathrm{DM}$ (average grass height $12.43 \mathrm{~cm}$ ) and $2048.89 \mathrm{~kg} / \mathrm{ha} \mathrm{DM}$ (average grass height 13.48 $\mathrm{cm})$, respectively.

The DM content of forage samples was determined; ash and total nitrogen $(\mathrm{N})$ were measured according to AOAC (1995); insoluble neutral detergent fiber (NDF) and insoluble acid detergent fiber (ADF) were assessed according to Robertson and Van Soest (1981). 
Table 1. Chemical composition of feed and experimental diets of crosbreed Dorper x Santa Ines lambs into distinct production systems.

\begin{tabular}{|c|c|c|c|c|c|c|}
\hline & \multicolumn{6}{|c|}{ Experimental Feed } \\
\hline Composition (g/kg) & \multicolumn{2}{|c|}{ Corn Meal } & \multicolumn{2}{|c|}{ Soybean Meal } & \multicolumn{2}{|c|}{ Wheat Bran } \\
\hline $\mathrm{DM}^{*}$ & \multicolumn{2}{|c|}{898,30} & \multicolumn{2}{|c|}{873,70} & \multicolumn{2}{|c|}{883,80} \\
\hline $\mathrm{CP}$ & \multicolumn{2}{|c|}{97,50} & \multicolumn{2}{|c|}{487,70} & \multicolumn{2}{|c|}{145,60} \\
\hline $\mathrm{NDF}$ & \multicolumn{2}{|c|}{162,00} & \multicolumn{2}{|c|}{165,20} & \multicolumn{2}{|c|}{453,70} \\
\hline $\mathrm{ADF}$ & \multicolumn{2}{|c|}{38,90} & \multicolumn{2}{|c|}{104,10} & \multicolumn{2}{|c|}{154,30} \\
\hline \multirow[t]{4}{*}{ TDN** } & \multicolumn{2}{|c|}{878,00} & \multicolumn{2}{|c|}{790,70} & \multicolumn{2}{|c|}{$770,40 *$} \\
\hline & \multicolumn{6}{|c|}{ Lambs Production Systems } \\
\hline & \multicolumn{3}{|c|}{ Concentrate } & \multicolumn{3}{|c|}{ Bulk $^{\S \S}$} \\
\hline & PAss & PAcs & COp & PAss & PAcs & COp \\
\hline $\mathrm{DM}^{*}$ & 881,27 & 881,27 & 884,38 & 27,07 & 25,49 & 898,40 \\
\hline $\mathrm{CP}$ & 190,47 & 190,47 & 214,77 & 138,90 & 150,97 & 62,00 \\
\hline NDF & 121,64 & 121,64 & 144,98 & 578,86 & 551,08 & 684,40 \\
\hline $\mathrm{ADF}$ & 64,76 & 64,76 & 65,27 & 430,19 & 432,09 & 439,80 \\
\hline TDN** & 837,67 & 837,67 & 839,76 & 577,27 & 575,94 & 545,90 \\
\hline
\end{tabular}

$\S$ Chemical composition of the concentrate and bulk fractions per treatment. ${ }^{\S}$ Chemical composition of simulation of contínuos grazing (PAss e PAcs) and ryegrass hay (COp). ${ }^{*} \mathrm{~g} / \mathrm{kg}$ of wet; **TDN estimate by Rodrigues (2009): TDN: 87,84 - (0,70 x ADF). DM: Dry Matter Content; CP: Crude Protein; NDF: Neutral Fiber Detergent; ADF: Acid Fiber Detergent; TDN: Total Digestible Nutrients; PAss: Grazing + supplementation without shading; PAcs: Grazing + supplementation + shading; COp: Cote Feedlot.

Table 2. Concentrate sources supplied to crossbreed Dorper x Santa Inês lambs into distinct production systems.

\begin{tabular}{lccc}
\hline & \multicolumn{3}{c}{ Lambs Production Systems } \\
\hline \multirow{2}{*}{ Feed $\mathbf{( g / k g )}$} & PAss & PAcs & COp* \\
\cline { 2 - 4 } & & & 634.90 \\
Corn Meal & 661.50 & 661.50 & 64.50 \\
Wheat Bran & 98.50 & 98.50 & 294.20 \\
Soybean Meal & 228.90 & 228.90 & 6.40 \\
Calcitic Lime & 11.10 & 11.10 & 1000.00 \\
Total & 1000.00 & 1000.00 & \\
\hline
\end{tabular}

* Diet composed by $80 \%$ de concentrate and $20 \%$ ryegrass hay; PAss: Grazing + supplementation without shading; PAcs: Grazing + supplementation + shading; COp: Cote Feedlot.

The duration of the treatments was determined according to performance, i.e. lambs were fed until reaching the pre-determined slaughter weight of 40 $\mathrm{kg} \mathrm{BW}$. At this point, the lambs were fasted for up to $16 \mathrm{~h}$ and then weighed to record $\mathrm{BW}$ at the time of slaughter and weight loss after fasting ([LAF]; in percent). The lambs were stunned by electronarcosis, followed by bleeding and subsequent evisceration according to the normative instruction no. 3 of January 17, 2000, of the Ministério da Agricultura e do Abastecimento - Secretaria de Defesa Agropecuária.

Non-carcass components such as heart, liver, pancreas, thymus, kidneys plus perirenal fat, spleen, diaphragm, esophagus, stomach, omental fat, small and large intestines, blood, skin, head, extremities, 
and the reproductive tract (testes and bladder) were collected and weighed to calculate perform the respective proportion of $\mathrm{BW}$ at slaughter (BWs).

The data were tested using an analysis of variance with the PROC Mixed procedure, and significantly different means were tested post hoc using a Tukey' test at a $5 \%$ level of significance. Statistical analyses were performed using the statistical package SAS Academic Edition (SAS Institute, Cary, NC).

\section{Results and Discussion}

The treatments significantly affected DWG, BCS, BWs, and LAF (Table 3). DWG differed significantly between the production systems $(\mathrm{p}=0.0041)$, with higher DWG in COp lambs. Carvalho et al. (2014) found lower DWG values when castrated lambs were finished in a comparable feedlot system (DWG from 0.140 to $0.196 \mathrm{~kg}$ ). Bernardes et al. (2015) recorded $0.218 \mathrm{~kg}$ DWG in castrated lambs of Texel breed. However, it is worth noting that the lambs used in the present study were not castrated, which typically results in faster growth, compared to castrated males and females (SILVA SOBRINHO et al., 2008). In feedlot pens, lambs can typically feed without the need for extensive movement, compared to grazing animals. This production system also allows monitoring the quantities of consumed food and adjustment of daily nutrient and dry matter intake.

Table 3. Dorper x Santa Ines crossbreed lambs pre-slaughtering characteristics into distinct production systems.

\begin{tabular}{lccccc}
\hline \multicolumn{7}{c}{ Lambs Productions Systems } \\
\hline PAss & PAcs & COp & CV\% & P value \\
\hline Age to slaughter (days) & $224.29 \pm 25.95$ & $235.14 \pm 23.45$ & $215.43 \pm 24.42$ & 11.02 & 0.3465 \\
DWG & $0.169 \pm 0.05 \mathrm{~b}$ & $0.147 \pm 0.03 \mathrm{~b}$ & $0.238 \pm 0.05 \mathrm{a}$ & 31.86 & 0.0041 \\
BCS & $3.14 \pm 0.55 \mathrm{~b}$ & $2.93 \pm 0.34 \mathrm{~b}$ & $4.07 \pm 0.34 \mathrm{a}$ & 19.22 & 0.0002 \\
BW & $40.00 \pm 1.48$ & $40.31 \pm 1.95$ & $41.34 \pm 1.18$ & 3.95 & 0.2705 \\
BWs & $36.93 \pm 1.27 \mathrm{~b}$ & $37.26 \pm 1.86 \mathrm{ab}$ & $39.21 \pm 1.57 \mathrm{a}$ & 4.84 & 0.0313 \\
Jejum Loss (\%) & $7.66 \pm 1.22 \mathrm{a}$ & $7.57 \pm 1.34 \mathrm{a}$ & $5.17 \pm 1.73 \mathrm{~b}$ & 26.76 & 0.0069 \\
\hline
\end{tabular}

$\mathrm{CV} \%$ : Coefficient of variation; Means followed by the same lower case letter in the row and column do not differ significantly among themselves by Tukey-Kramer test $(\mathrm{p}<0,05)$; PAss: Grazing + supplementation without shading; PAcs: Grazing + supplementation + shading; COp: Cote Feedlot.; DWG: Daily weight gain (kg); BCS: Body conditions score in slaughter; BW: Body weight / weight before shipment of animals $(\mathrm{kg})$; BWs: Body weight at slaughter $(\mathrm{kg})$.

DWG did not differ between finishing on the shaded pasture and in the silvopastoral system. Silveira et al. (2015) found a daily weight gain of $0.128 \mathrm{~kg}$ in crossbred Santa Inês lambs on an aruana pasture with diet supplementation was lower than in PAss and PAcs systems. The development of lambs, both on pasture and in feedlot pens can be assessed by BCS which serves as an indication of the level of finishing (fat content) in vivo. COp lambs had a higher mean BCS $(p=0.0002)$ and had the highest BWS, however, it did not differ significantly from that of lambs in the silvopastoral system. Weight loss due to fastening was calculated based on the difference between BWs and the last weighing before slaughter. The lowest amounts of weight loss was observed in COp lambs, as this parameter is correlated with the dietary proportion of roughage to concentrate $(20: 80)$. Considering that the largest fraction of the diet in the confinement was the concentrate $(80 \%)$ which is characterized by a relatively short gut passage time likely explains the smaller weight losses after fasting. In contrast, 
lambs on pasture showed higher weight loss after fasting, with similar results in both pasture systems, resulting from longer gut passage time of roughage.

The retention time of roughage is considered a factor that may limit intake, mainly due to the anatomical capacity of the rumen and reticulum, and subsequently lower nutrient intake thus reduces performance (CARVALHO et al., 2005). However, the complex digestive system of ruminants facilitates the digestion of fibrous foods, which are easily converted to volatile fatty acids that serve as energy source for the production of ATP (MACEDO JÚNIOR et al., 2007) used for tissue synthesis. According to Silva Sobrinho (2006), weight loss after a fasting period should be approximately
$6 \%$, and a higher loss may compromise the true or biological yield of the carcass.

The non-carcass component yield was influenced by the production systems (Table 4), apart from the empty gastrointestinal tract (EGT) and the respiratory and reproductive organs $(p>0.05)$. The yield of the blood component also differed between the production systems $(p=0.0125)$. The highest amount was achieved in the COp system, and similar value were observed in the Pass system; no significant difference was observed between the pasture systems. Clementino et al. (2007) and Pompeu et al. (2013) confirmed that BW is positively correlated with the amount of blood.

Table 4. Dorper x Santa Ines crossbreed lambs non-carcass compounds into distinct production systems.

\begin{tabular}{lccccc}
\hline \multicolumn{7}{c}{ Lambs Production Systems } \\
\hline PAss & PAcs & COp & CV\% & P value \\
\hline Blood & $4.42 \pm 0.35 \mathrm{ab}$ & $4.28 \pm 0.32 \mathrm{~b}$ & $4.81 \pm 0.30 \mathrm{a}$ & 8.20 & 0.0125 \\
Others components & $14.70 \pm 1.13 \mathrm{ab}$ & $13.45 \pm 0.77 \mathrm{~b}$ & $15.72 \pm 1.13 \mathrm{a}$ & 8.95 & 0.0012 \\
FGT & $21.38 \pm 2.01 \mathrm{~b}$ & $24.25 \pm 2.50 \mathrm{a}$ & $18.76 \pm 1.40 \mathrm{c}$ & 13.58 & 0.0002 \\
EGT & $8.83 \pm 1.24$ & $8.65 \pm 0.87$ & $8.01 \pm 0.65$ & 10.74 & 0.2210 \\
Lungs + trachea & $1.21 \pm 0.13$ & $1.20 \pm 0.16$ & $1.18 \pm 0.08$ & 9.86 & 0.8639 \\
Kidney + fat & $0.74 \pm 0.33 \mathrm{~b}$ & $0.59 \pm 0.17 \mathrm{~b}$ & $1.21 \pm 0.47 \mathrm{a}$ & 48.42 & 0.0057 \\
Liver & $1.59 \pm 0.11 \mathrm{~b}$ & $1.52 \pm 0.08 \mathrm{~b}$ & $1.77 \pm 0.15 \mathrm{a}$ & 9.32 & 0.0015 \\
Heart & $0.38 \pm 0.05 \mathrm{~b}$ & $0.38 \pm 0.03 \mathrm{~b}$ & $0.44 \pm 0.05 \mathrm{a}$ & 12.52 & 0.0277 \\
Spleen & $0.14 \pm 0.01 \mathrm{~b}$ & $0.15 \pm 0.02 \mathrm{~b}$ & $0.18 \pm 0.02 \mathrm{a}$ & 16.85 & 0.0046 \\
Reproductive System & $1.25 \pm 0.15$ & $1.32 \pm 0.22$ & $1.27 \pm 0.21$ & 14.01 & 0.7644 \\
OmF & $0.73 \pm 1.17 \mathrm{~b}$ & $0.68 \pm 0.20 \mathrm{~b}$ & $1.24 \pm 0.36 \mathrm{a}$ & 38.93 & 0.0006 \\
\hline
\end{tabular}

$\mathrm{CV} \%$ : Coefficient of variation; ; Means followed by the same lower case letter in the row and column do not differ significantly among themselves by Tukey-Kramer test $(\mathrm{p}<0,05)$; PAss: Grazing + supplementation without shading; PAcs: Grazing + supplementation + shading; COp: Cote Feedlot; Others: extremities, skin and head; FGT: full gastrointestinal tract; EGT: empty gastrointestinal tract; A; OmF: Omentum Fat; Means expressed as carcass percentage.

Moreover, significant differences between systems were also observed in the non-edible components (Table 4), which were pooled for statistical testing. According to Pompeu et al. (2013), the weight of skin, which has the highest weight of all non-edible components, is also positively correlated with BW. Therefore, the results on non- edible components observed in the present study may be due to the larger amount of skin in animals of higher BW.

The weight of the full gastrointestinal tract (FGT) differed significantly between the treatments $(p=0.0002)$, with the highest FGT weight in the two pasture systems, and FGT weight of COp lambs was 
lower than in lambs on pasture. Similar results were reported by Macedo et al. (2003) regarding pasturefeed lambs (26.74\%) and COp lambs (21.29\%).

The weight of the emptied gastrointestinal tract (EGT) showed no effect of the treatment $(\mathrm{p}=$ 0.2210). Thus, the weight of the gastrointestinal tract was similar, but filling capacity differed between treatments. Thus, diet contributed to FGT weight, as the bulk food occupies more physical space in the rumen and remains longer in the intestines than concentrate.

The weight of kidneys and perirenal fat differed between production systems $(\mathrm{p}=0.0057)$ and was higher in the COp system and similar in lambs of the two pasture treatments; a positive correlation of kidney weight and BCS was observed. Moreover, omental fat content differed significantly between treatments $(p=0.0007)$ and was highest in COp animals; no significant difference was observed between the two pasture systems. Carvalho et al. (2014) observed that the confinement provided greater amount of internal and renal fat, when compared to the finishing in the pasture, due to the greater intensity of the food intake. The weights of liver, heart, and spleen relative to BWs, differed among the production systems (1.92, 0.47 and $0.20 \%$, respectively), being higher for lambs of COp.

Clementino et al. (2007) observed that diets containing high proportions of concentrate influence the amount of blood and the weight liver, kidneys, spleen, and heart. A similar pattern was observed in the COp treatment of the present study, which produced higher yield than the pasture treatments.

According to Kozloski (2016), the food, after ingestion, goes through various physical and chemical processes along the gastrointestinal tract, allowing the degradation of the more complex structures of the food. After this transformation, the smaller particles are easily absorbed into the bloodstream and all nutrients are transported through the blood with a greater intensity.
In this way, the increase of the flow through the venous system occurs directly to the liver, which is considered as responsible for the regulation of nutrients that will be converted to the production. Nutrient conversion in the liver is a consequence of digestion and nutrient absorption processes, and it is influenced by diet composition and blood flow. Thus, the proportion of concentrate in the diet of COp animals resulted in increased activity of the digestive system, causing differences in the weight of the heart, liver, and spleen, compared to the pasture systems. The COp system promoted accelerated weight gain as a consequence of higher activity of the digestive system and increased absorption of nutrients. Comparing effective productivity between COp and pasture systems and improving the efficiency of each of these systems need to be investigated further in order to optimize production according to the current demand and production costs.

\section{Conclusions}

The studied production systems affected the yield of non-carcass components of Dorper x Santa Inês crossbred lambs. The two pasture systems were similar, and the highest yields were achieved in the feedlot pen system.

\section{Acknowledgements}

We thank the Coordenação de Aperfeiçoamento de Pessoal de Nível Superior (CAPES) for financial support of this study (finance code 001).

\section{References}

ANDRADE, M. B.; MACEDO, F. D. A. F.; JOBIM, C. C.; LOMBARDI, L.; MACEDO, F. G.; GASPARINO, E. Características da carcaça e da carne de cordeiros terminados com dietas contendo diferentes proporções de silagens de grãos de milho. Acta Scientiarum. Animal Sciences, Maringá, v. 31, n. 2, p. 183-189, 2009. DOI: 10.4025/actascianimsci.v31i2.3451 
ASSOCIATION OF OFFICIAL ANALYTICAL CHEMISTRY - AOAC. Official methods of analysis. $16^{\text {th }}$ ed. Washington: AOAC International, 1995. 1094 p.

BERNARDES, G. M. C.; CARVALHO, S.; PIRES, C. C.; MOTTA, J. H.; TEIXEIRA, W. S.; BORGES, L. I.; VENTURINI, R. S. Consumo, desempenho e análise econômica da alimentação de cordeiros terminados em confinamento com o uso de dietas de alto grão. Arquivo Brasileiro de Medicina Veterinária e Zootecnia, Belo Horizonte, v. 67, n. 6, p. 1684-1692, 2015. DOI: 10.1590/1678-4162-7934

BRASIL. Ministério da Agricultura, Pecuária e Abastecimento. Regulamento da Inspeção Industrial e Sanitária de Produtos de Origem Animal, n 9.013 de 29 março de 2017. (RIISPOA). Diário Oficial [da] União, Brasília, 29 mar. 2017. Edição 62, Seção 1, p. 3.

CARVALHO, S.; PIRES, C. C.; MACARI, S.; LOPES, J. F.; MORO, A. B.; VENTURINI, R. S.; TEIXEIRA, R. S. Características produtivas de cordeiros terminados em confinamento com dietas contendo diferentes teores de borra de soja. Arquivo Brasileiro de Medicina Veterinária e Zootecnia, Belo Horizonte, v. 66, n. 1, p. 259-267, 2014. DOI: $10.1590 / \mathrm{S} 0102-09352014000100035$

CARVALHO, S.; VERGUEIRO, A.; KIELING, R.; TEIXEIRA, R. C.; PIVATO, J.; VIERO, R.; CRUZ, A. L. da. Avaliação da suplementação concentrada em pastagem de Tifton-85 sobre os componentes não carcaça de cordeiros. Ciência Rural, Santa Maria, v. 35, n. 2 , p. $435-439$, mar./abr. 2005. DOI: $10.1590 / \mathrm{S} 0103-$ 84782005000200030

CLEMENTINO, R. H.; SOUSA, W. H.; MEDEIROS, A. N.; CUNHA, M. D. G. G.; GONZAGA NETO, S.; CARVAlHO, F. F. R. D. Influência dos níveis de concentrado sobre os cortes comerciais, os constituintes não-carcaça e os componentes da perna de cordeiros confinados. Revista Brasileira de Zootecnia, Viçosa, MG, v. 36, n. 3, p. 681-688, 2007. DOI: 10.1590/S151635982007000300023

COSTA, R. G.; SANTOS, N. M.; MEDEIROS, A. N.; MADRUGA, M. S.; QUEIROGA, R. C. R. E. Buchada Caprina: características físico-químicas e microbiológicas. Campina Grande: Editora Impressos Adilson, 2007. $93 \mathrm{p}$.

HUTCHISON, G. I.; NGA, H. H.; KUO, Y. L.; GREENFIELD, H. Composition of Australian foods, 36. Beef, lamb and veal offal. Food Technology Australian, Sydney, v. 39, n. 5, p. 223-227, 1987.

KOZLOSKI, G. V. Bioquímica dos ruminantes. 3. ed. rev. ampl. Santa Maria: Editora da Universidade Federal de Santa Maria, UFSM, 2016. 209 p.
LIMA, N. L. L.; SILVA SOBRINHO, A. G. D.; ALMEIDA, F. A. D.; ENDO, V.; ZEOLA, N. M. B. L.; ALMEIDA, A. K. D.; SAMPAIO, A. A. M. Quantitative and qualitative characteristics of the non-carcass components and the meat of lambs fed sunflower seeds and vitamin E. Revista Brasileira de Zootecnia, Viçosa, MG, v. 42, n. 1, p. 51-60, 2013. DOI: 10.1590/S151635982013000100008

MACEDO JÚNIOR, G. de L.; ZANINE, A. de M.; BORGES, I.; PÉREZ, J. R. O. Qualidade da fibra para a dieta de ruminantes. Ciência Animal, Santa Maria, v. 17, n. 1, p. 7-17, 2007.

MACEDO, F. D. A. F.; MARTINS, E. N.; SIQUEIRA, E. R. de; NIETO, L. M.; MACEDO, R. M. G. de; SAKAGUTI, E. S. Componentes do peso vivo de cordeiros Corriedale, puros e mestiços, terminados em pastagem ou confinamento. Arquivos de Ciências Veterinárias e Zoologia da UNIPAR, Umuarama, v. 6, n. 1, p. 53-56, 2003. DOI: 10.25110/arqvet.v6i1.2003.796

MATTOS, C. W.; CARVALHO, F. F. R.; DUTRA JUNIOR, W. M.; VÉRAS, A. S. C.; BATISTA, A. M. V.; ALVES, K. S.; RIBEIRO, V. L.; SILVA, M. J. M. S.; MEDEIROS, G. R.; VASCONCELOS, M. J.; ARAÚJO, A. O.; MIRANDA, S. B. Características de carcaça e dos componentes não-carcaça de cabritos Moxotó e Canindé submetidos a dois níveis de alimentação. Revista Brasileira de Zootecnia, Viçosa, MG, v. 35, n. 5, p. 2125 2134, 2006. DOI: 10.1590/S1516-35982006000700033

MOTT, G. O.; LUCAS, H. L. The design, conduct, and interpretation of grazing trials on cultivated and improved pastures. In: INTERNATIONAL GRASSLAND CONGRESS, 6., 1952, Pennsylvania. Proceedings... Pennsylvania: [s.n.], 1952. p. 1380-1385.

NATIONAL RESEARCH COUNCIL - NRC. Nutrients requirements of small ruminants. $6^{\text {th }}$ ed. Washington: Editora The National Academies Press, 2007. 341 p.

PÉREZ, J. R. O.; CARVALHO, P. A. Considerações sobre carcaças ovinas. Ovinocultura: aspectos produtivos. Lavras: GAO, 2002. 29 p.

POMPEU, R. C. F. F.; BESERRA, L. T.; CÂNDIDO, M. J. D.; BOMFIM, M. A. D.; VIEIRA, M. M. M.; ANDRADE, R. R. D. Características da carcaça e dos componentes não-carcaça de ovinos alimentados com dietas contendo casca de mamona. Revista Brasileira de Saúde e Produção Animal, Salvador, v. 14, n. 3, p. 490507, 2013. DOI: 10.1590/S1519-99402013000300011

ROBERTSON, J. B.; VAN SOEST, P. J. The detergent system of analysis. In: JAMES, W. P. T.; THEANDER, O. (Ed.) The analysis of dietary fibre in food. New York: Marcel Dekker, 1981. p. 123-158. 
RODRIGUES, R. C. Avaliação químico-bromatológica de alimentos produzidos em terras baixas para nutrição animal. Pelotas: Empresa Brasileira de Pesquisa Agropecuária - EMBRAPA, 2009. 31 p.

RUSSEL, A. J. F.; DONEY, J. M.; GUNN, R. G. Subjective assessment of body fat in live sheep. Journal Agricultural Science, Edinburgh, v. 72, n. 3, p. 451-454, 1969. DOI: $10.1017 / \mathrm{S} 0021859600024874$.

SANTOS, N. M.; COSTA, R. G.; MEDEIROS, A. N.; MADRUGA, M. S.; GONZAGA NETO, S. Caracterização dos componentes comestíveis não constituintes da carcaça de caprinos e ovinos. Agropecuária Técnica, Areia, v. 26, n. 2, p. 77-85, 2005.

SILVA SOBRINHO, A. G. Criação de ovinos. 3. ed. Jaboticabal: FUNEP, 2006. 302 p.
SILVA SOBRINHO, A. G.; OSÓRIO, J. C. S. Aspectos quantitativos da produção de carne ovina. In: SILVA SOBRINHO, A. G.; SAÑUDO, C.; OSÓRIO, J. C. S.; ARRIBAS, M. M. C.; OSÓRIO, M. T. M. Produção de carne ovina. Jaboticabal: FUNEP, 2008. p. 1-68.

SILVEIRA, M. F.; MACEDO, V. P.; BATISTA, R.; SANTOS, G. B.; NEGRI, R.; CASTRO, J. M.; SILVEIRA $\mathrm{L}$. W. Ingestive behavior and productive performance of lambs maintained in tropical pasture receiving different supplements. Arquivo Brasileiro de Medicina Veterinária e Zootecnia, Belo Horizonte, v. 67, n. 4, p. 1125-1132, 2015. DOI: $10.1590 / 1678-4162-8255$.

WILM, H. G.; COSTEllO, D. F.; KLIPPLE, G. E. Estimating forage yield by the 11 double-sampling methods. Journal of American Society of Agronomy, Fort Collins, v. 36, n. 12, p. 194-203, 1944. 
